\title{
PENGARUH UMUR DAN PENYAKIT PENYERTA TERHADAP RESIKO INFEKSI LUKA OPERASI PADA PASIEN BEDAH GASTROINTESTINAL
}

\section{THE INFLUENCE OF AGE AND COMORBIDITY TO THE RISK OF SURGICAL SITE INFECTION ON THE PATIENTS OF GASTROINTESTINAL SURGERY}

\author{
Imaniar Noor Faridah ${ }^{1)}$, Tri Murti Andayani ${ }^{2)}$, Inayati ${ }^{3)}$ \\ Fakultas Farmasi Universitas Ahmad Dahlan \\ Jl. Prof. Dr. Supomo Yogyakarta, Telp. (0274) 379418
}

\begin{abstract}
Abstrak
Infeksi luka operasi (Surgical Site Infection/SSI) merupakan hasil kontaminasi bakteri yang masuk saat operasi berlangsung. Karakteristik pasien seperti umur dan penyakit penyerta memiliki resiko tinggi terhadap kejadian SSI, sebab berhubungan dengan sistem imunitas tubuh. Tujuan dari penelitian ini adalah untuk mengetahui pengaruh umur dan penyakit penyerta terhadap resiko kejadian SSI pada pasien bedah gastrointestinal. Penelitian ini merupakan penelitian cross sectional yang dilakukan secara prospektif di Rumah Sakit PKU Muhammadiyah Yogyakarta pada periode Januari hingga Maret 2012. Kriteria inklusi pasien adalah pasien rawat inap yang menjalani operasi gastrointestinal, luka bekas operasi pasien dapat terlihat, serta menggunakan antibiotik yang bertujuan untuk pencegahan infeksi luka operasi. Pada penelitian ini diperoleh 68 pasien yang memenuhi kriteria inklusi. Data yang dianalisa berupa karakteristik pasien yaitu umur dan penyakit penyerta terhadap resiko kejadian SSI. Dari penelitian ini diperoleh 2 pasien (2,94\%) yang mengalami kejadian SSI. Berdasarkan umur pasien, SSI terjadi pada 2 pasien yang keduanya berada pada rentang usia 41-60 tahun, namun berdasarkan hasil perhitungan statistik diketahui tidak terdapat hubungan antara umur dengan kejadian SSI ( $p>0.05)$. Berdasarkan penyakit penyerta, SSI terjadi pada 2 pasien yang keduanya memiliki penyakit penyerta, dan berdasarkan hasil perhitungan statistik diketahui bahwa terdapat hubungan antara keberadaan penyakit penyerta dengan kejadian SSI $(p<0.05)$.
\end{abstract}

Kata kunci : Infeksi luka operasi, bedah gastrointestinal, karakteristik pasien

\footnotetext{
${ }^{2)}$ Fakultas Farmasi Universitas Gadjah Mada

${ }^{3)}$ Instalasi Farmasi Rumah Sakit PKU Muhammadiyah Yogyakarta
} 


\section{Abstract}

Surgical Site Infection / SSI is the result of the contamination of bacteria which enter the body during surgery. High risk of SSI is occured in gastrointestinal surgery and influenced by the characteristics of the patients such as age and comorbidity since they deal with immunity system of the body. The research was aimed to identity the influence of age and comorbidity to the high risk of SSI in gastrointestinal surgery patients. The research was a cross sectional research conducted prospectively at $P K U$ Muhammadiyah Hospital Yogyakarta from January to March 2012. The research subjects were all inpatients undergoing gastrointestinal surgery, having visible surgical site and using antibiotic to prevent surgical site infection. There are 68 patients in the research. Data that were analyzed comprised the characteristics of patients such as age and congenital disease to the risk of surgical site infection. The result of this research indicated that 2 patients (2,94\%) suffering SSI. Based on the age, SSI happened to 2 patients in the age range of 41-60 years old. However, based on the statistical result, there was no correlation between age and the existence of SSI $(p>0.05)$. SSI also occured in 2 patients with comorbidity. However, there was correlation between the existence of comorbidity and SSI $(p<0.05)$.

Keywords : Surgical site infection, gastrointestinal surgery, characteristics of patients

\section{PENDAHULUAN}

Infeksi luka operasi (Surgical Site Infection/SSI) merupakan hasil dari kontaminasi bakteri yang masuk saat operasi berlangsung atau setelah operasi. Data yang diperoleh dari National Nosocomial Infection Surveillace (NNIS) mengindikasikan bahwa infeksi luka operasi merupakan infeksi ketiga tersering yang terjadi di rumah sakit dengan sekitar $14-16 \%$ dari total pasien di rumah sakit mengalami infeksi luka operasi (Doherty, 2006). Dampak yang akan diperoleh dari kejadian SSI adalah peningkatan biaya pengobatan serta peningkatan mortalitas dan morbiditas yang berhubungan dengan pembedahan.
Beberapa hal yang perlu diwaspadai dalam usaha menurunkan angka kejadian SSI adalah risiko kemungkinan terkena SSI. Beberapa risiko tersebut tergantung pada karakteristik pasien, operasi yang dilakukan, staf healthcare dan rumah sakit (Tietjen dkk, 2003). Karakteristik pasien yang perlu diwaspadai terhadap resiko kemungkinan terkena SSI adalah umur pasien dan penyakit penyerta yang dialami pasien. Umur pasien perlu diwaspadai terkait hubungannya dengan kejadian SSI, misalnya pada kasus geriatri terdapat banyak kemungkinan penyakit yang akan muncul dan mempengaruhi kejadian SSI seperti menurunnya ketahanan imunologis 
tubuh, malnutrisi, hipoalbumin, dan intake yang kurang adekuat sering terjadi pada usia lanjut (Kaye, 2004). Sedangkan penyakit penyerta pasien perlu diwaspadai terutama pada penyakit penyerta diabetes dan gangguan sistem imun. Gangguan yang terjadi berkaitan dengan umur dan penyakit penyerta tersebut dikhawatirkan dapat mempengaruhi proses penyembuhan luka pasca operasi yang dilakukan oleh pasien.

\section{Rumah}

Sakit

PKU Muhammadiyah merupakan suatu rumah sakit yang banyak menerima pasien yang akan melakukan pembedahan setiap harinya. Sehingga dengan penelitian ini diharapkan dapat diperoleh suatu informasi mengenai hubungan antara umur dan penyakit penyerta pasien dengan terjadinya infeksi luka operasi pada pasien operasi gastrointestinal di Rumah Sakit PKU Muhammadiyah Yogyakarta.

Tujuan penelitian ini adalah untuk mengetahui hubungan antara karakteristik pasien yaitu umur dan penyakit penyerta terhadap kejadian infeksi luka operasi pada pasien bedah gastrointestinal di Rumah Sakit PKU Muhammadiyah Yogyakarta.

\section{METODE PENELITIAN}

\section{Rancangan Peneliti}

Penelitian ini merupakan
penelitian cross sectional yang
dilakukan secara prospektif, yaitu
dengan melihat karakteristik pasien
berupa umurdan penyakit penyerta yang
berperan pada kejadian infeksi luka
operasi di Rumah Sakit PKU

Muhammadiyah Yogyakarta pada periode Januari hingga Maret 2012

\section{Subyek Penelitian}

Subyek penelitian ini adalah semua pasien rawat inap yang menjalani operasi bagian gastrointestinal pada bulan Januari hingga Maret 2012 dan menggunakan antibiotik di Rumah Sakit PKU Muhammadiyah Yogyakarta yang memenuhi kriteria inklusi.

\section{Sampel Penelitian}

Sampel diambil berdasarkan waktu penelitian yaitu pada bulan Januari hingga Maret 2012. Kriteria inklusi penelitian ini adalah pasien rawat inap yang menjalani operasi gastrointestinal, luka bekas operasi dapat terlihat, serta menggunakan antibiotik yang bertujuan untuk pencegahan infeksi luka operasi. Kriteria eksklusi penelitian ini adalah pasien yang sedang dalam terapi antibiotik sebelumnya karena adanya penyakit infeksi, pasien yang menginap di rumah sakit kurang dari 3 hari, serta pasien yang tidak memiliki kelengkapan data.

\section{Analisis Data}

Data yang diperoleh berupa karakteristik pasien yaitu umur dan penyakit penyerta. Data tersebut kemudian dianalisis dengan menghasilkan persentase karakteristik pasien terhadap kejadian infeksi luka operasi, serta dilakukan analisis statistik dengan menggunakan uji Chi Square jika memenuhi syarat. Syarat uji Chi Square adalah tidak adanya nilai expected kurang dari lima. Jika tidak memenuhi syarat dapat menggunakan uji Fisher 
untuk tabel $2 \times 2$ atau uji Kolmogorov Smirnov untuk tabel $2 \mathrm{x}$ k.

\section{HASIL DAN PEMBAHASAN}

Hasil penelitian ini diperoleh 68 pasien yang menjalani bedah gastrointestinal dan memenuhi kriteria inklusi. Hal yang perlu diwaspadai pada kejadian infeksi luka operasi adalah beberapa resiko dari pasien yang dapat mempengaruhi kejadian infeksi luka operasi, seperti umur dan penyakit penyerta pasien. Kejadian infeksi luka operasi pada penelitian ini terjadi pada 2 pasien $(2,94 \%)$ dari 68 pasien.

\section{Karakteristik umur pasien terhadap kejadian infeksi luka operasi}

Distribusi pasien berdasarkan umur pasien dibagi menjadi 4 kategori, yaitu umur kurang dari 20 tahun, 21 hingga 40 tahun, 41 hingga 60 tahun, dan lebih dari 61 tahun. Distribusi pasien berdasarkan umur disajikan pada Tabel I.

Pada Tabel I menunjukkan hasil bahwa dari 68 pasien yang dilakukan operasi gastrointestinal berdasarkan umur pasien paling banyak adalah pada usia muda yaitu kurang dari 20 tahun sebanyak 23 pasien $(33,82 \%)$ dengan usia termuda yaitu 7 tahun. Dari penelitian ini juga terdapat pasien geriatri ( $>61$ tahun) yang dilakukan operasi gastrointestinal yaitu sebanyak 8 pasien $(11,76 \%)$ dengan usia tertua yaitu 82 tahun.

Berdasarkan penelitian yang dilakukan oleh Korner (1997) diketahui bahwa insidensi kejadian apendisitis tanpa perforasi maupun dengan perforasi tertinggi terjadi pada usia remaja hingga dewasa tua (13-40 tahun). Apendisitis jarang terjadi pada anak-anak di bawah umur 5 tahun dan pada umur lebih dari 50 tahun. Pada umur 70 tahun ke atas, risiko apendisitis berkurang menjadi 1:100 (Prystowsky dkk, 2005).

Pada penelitian ini diperoleh 2 pasien yang mengalami infeksi luka operasi, dan keduanya berasal dari rentang usia 41 - 60 tahun. Namun berdasarkan hasil perhitungan statistik diperoleh hasil bahwa tidak terdapat

Tabel I. Karakteristik Umur Pasien Terhadap Infeksi Luka Operasi Pada Pasien Bedah Gastrointestinal di Rumah Sakit PKU Muhammadiyah Yogyakarta

\begin{tabular}{|c|c|c|c|c|c|c|c|}
\hline \multirow{2}{*}{$\begin{array}{l}\text { Umur } \\
\text { Pasien }\end{array}$} & \multicolumn{2}{|c|}{ Infeksi } & \multicolumn{2}{|c|}{ Tidak Infeksi } & \multicolumn{2}{|c|}{ Jumlah } & \multirow[b]{2}{*}{$P$} \\
\hline & $\Sigma$ Kasus & $\begin{array}{c}\% \\
(n=68)\end{array}$ & $\Sigma$ Kasus & $\begin{array}{c}\% \\
(n=68)\end{array}$ & $\sum$ Kasus & $\begin{array}{c}\% \\
(n=68)\end{array}$ & \\
\hline$<20$ & - & - & 23 & 33,82 & 23 & 33,82 & \multirow{4}{*}{$0,354^{*}$} \\
\hline $21-40$ & - & - & 21 & 30,88 & 21 & 30,88 & \\
\hline $41-60$ & 2 & 2,94 & 14 & 20,59 & 16 & 23,53 & \\
\hline$>61$ & - & - & 8 & 11,76 & 8 & 11,76 & \\
\hline Jumlah & 2 & 2,94 & 66 & 97,06 & 68 & 100 & \\
\hline
\end{tabular}

Ket : * = Uji Kolmogorov Smirnov 
hubungan antara umur pasien dengan infeksi luka operasi $(\mathrm{p}>0,05)$.

Peningkatan risiko terjadi infeksi luka operasi biasa terjadi pada usia ekstrim yaitu sangat tua (geriatri) atau sangat muda. Umur termasuk faktor risiko dari terjadinya infeksi luka operasi yang berasal dari kondisi pasien, dan pada usia lanjut berkaitan dengan menurunnya daya tahan tubuh (Anonim, 2008 ; Mangram, 1999). Pada penelitian ini infeksi luka operasi terjadi pada pasien dewasa tua (41 - 60 tahun), dan pada usia geriatri maupun anak-anak tidak terjadi infeksi luka operasi. Hal tersebut dapat terjadi karena pencegahan terhadap infeksi luka operasi tersebut dilakukan dengan seksama dan terkontrol.

Meskipun diketahui bahwa umur merupakan salah satu faktor risiko kejadian infeksi luka operasi, namun hubungan langsung antara umur dan infeksi luka operasi tersebut masih belum jelas. Penelitian menunjukkan hasil yang berbeda-beda, beberapa penelitian menunjukkan bahwa faktor risiko terhadap kejadian infeksi luka operasi tidak tergantung pada peningkatan umur pasien. Pada penelitian ini diketahui tidak terdapat hubungan antara umur pasien dengan kejadian infeksi luka operasi, hal tersebut juga dapat disebabkan karena jumlah sampel yang terlalu kecil.

Banyak hal yang dapat menghubungkan antara peningkatan umur dengan peningkatan risiko infeksi luka operasi, misalnya banyaknya penyakit yang berhubungan dengan peningkatan umur, menurunnya ketahanan imunologis tubuh, malnutrisi, hipoalbumin, dan intake yang kurang adekuat sering terjadi pada usia lanjut (Kaye, 2004).

\section{Karakteristik penyakit penyerta pasien terhadap kejadian infeksi luka operasi}

Distribusi pasien berdasarkan penyakit penyerta dibagi menjadi pasien yang memiliki penyakit penyerta baik diabetes dan non diabetes yang meliputi hipertensi, batuk, stroke ringan, tuberkulosis, keratitis pada mata, dan pasien yang tanpa penyakit penyerta. Distribusi pasien berdasarkan penyakit penyerta disajikan pada Tabel II.

Tabel II. Karakteristik Penyakit Penyerta Pasien Terhadap Infeksi Luka Operasi Pada Pasien Bedah Gastrointestinal di Rumah Sakit PKU Muhammadiyah Yogyakarta

\begin{tabular}{cccccccc}
\hline & \multicolumn{2}{c}{ Infeksi } & \multicolumn{2}{c}{ Tidak Infeksi } & \multicolumn{2}{c}{ Jumlah } & \\
\cline { 2 - 7 } $\begin{array}{c}\text { Penyakit } \\
\text { Penyerta }\end{array}$ & $\sum$ Kasus & $\begin{array}{c}\text { \% } \\
(\mathbf{n = 6 8 )}\end{array}$ & $\sum$ Kasus & $\begin{array}{c}\text { \% } \\
(\mathbf{n = 6 8 )}\end{array}$ & $\sum$ Kasus & $\begin{array}{c}\text { \% } \\
(\mathbf{n = 6 8 )}\end{array}$ & \\
\hline Ada & 2 & 2,94 & 13 & 19,12 & 15 & 22,06 & \multirow{2}{*}{ P $046^{*}$} \\
Tidak & - & - & 53 & 77,94 & 53 & 77,94 & \\
\hline Jumlah & 2 & 2,94 & 66 & 97,06 & 68 & 100 & \\
\hline
\end{tabular}

Ket : $*$ Uji Fisher 
Distribusi pasien berdasarkan penyakit penyerta yang dialami pasien sebagian besar tanpa penyakit penyerta yaitu sebanyak 53 pasien $(77,94 \%)$, namun 15 pasien lainnya $(22,06 \%)$ memiliki penyakit penyerta seperti adanya diabetes pada 1 pasien $(1,47 \%)$, dan non diabetes pada 14 pasien $(20,59 \%) \quad$ (Tabel III). Namun berdasarkan hasil perhitungan statistik diperoleh hasil bahwa terdapat hubungan antara keberadaan penyakit penyerta dengan infeksi luka operasi $(\mathrm{p}<0,05)$.

Penyakit non diabetes yang dialami yaitu hipertensi (11,77\%), batuk $(4,41 \%)$, stroke ringan $(1,47 \%)$, tuberkulosis $(1,47 \%)$ dan Oculuc Dexter et Sinister (ODS) keratitis (1,47\%). Pada tabel III diketahui bahwa terjadi infeksi luka operasi pada 2 pasien $(13,33 \%)$ yang memiliki penyakit penyerta non diabetes.

Kejadian infeksi luka operasi terjadi pada 2 pasien yang mengalami batuk. Penyebab batuk terhadap kejadian infeksi luka operasi tidak dapat dihubungkan secara langsung, sebab banyak faktor yang akan mempengaruhi kejadian infeksi luka operasi. Namun dapat terjadi infeksi luka operasi jika luka bekas operasi tidak terlalu rapat dikarenakan pasien terus batuk, sehingga memudahkan kontaminan untuk masuk ke dalam bekas operasi tersebut.

Penyakit penyerta lain yang dialami pasien seperti diabetes terutama pada pasien yang memiliki kelebihan gula darah yang tidak terkontrol saat perioperasi diketahui dapat meningkatkan risiko terhadap infeksi luka operasi (Kanji, 2008). Diketahui juga bahwa peningkatan level glukosa ( $>200 \mathrm{gm} / \mathrm{dL}$ ) pasca operasi $(\leq 48$ jam) berhubungan dengan peningkatan risiko terjadinya infeksi luka operasi (Mangram, 1999). Pada penelitian ini terdapat satu pasien yang saat masuk rumah sakit mengalami hiperglikemia dan kemudian didiagnosis diabetes. Tetapi dengan pengontrolan yang baik terhadap kadar gula darah pasien ini, mengakibatkan operasi dan hasil bekas luka operasi pasien dalam keadaan baik.

Keterbatasan penelitian ini, yaitu :

1. Pengambilan jumlah sampel hanya berdasarkan bulan yaitu bulan Januari hingga Maret 2012, dan jumlah sampel yang diperoleh tidak banyak sehingga belum dapat menggambarkan data yang sempurna.

Tabel III. Karakteristik Jenis Penyakit Penyerta Pasien Terhadap Infeksi Luka Operasi Pada Pasien Bedah Gastrointestinal di Rumah Sakit PKU Muhammadiyah Yogyakarta

\begin{tabular}{ccccccc}
\multirow{2}{*}{$\begin{array}{c}\text { Penyakit } \\
\text { Penyerta }\end{array}$} & \multicolumn{2}{c}{ Infeksi } & \multicolumn{2}{c}{ Tidak Infeksi } & \multicolumn{2}{c}{ Jumlah } \\
\cline { 2 - 7 } & $\sum$ Kasus & \% & $\sum$ Kasus & \% & $\sum$ Kasus & $\%$ \\
\hline Diabetes & - & - & 1 & 6,67 & 1 & 6,67 \\
$\begin{array}{c}\text { Non } \\
\text { Diabetes }\end{array}$ & 2 & 13,33 & 12 & 80 & 14 & 93,33 \\
\hline Jumlah & 2 & 13,33 & 13 & 86,67 & 15 & 100 \\
\hline
\end{tabular}


2. Pengamatan tanda dan gejala infeksi luka operasi tidak dilakukan dalam 24 jam, sehingga peneliti memerlukan data pendukung seperti rekam medis dan catatan perawat.

\section{KESIMPULAN DAN SARAN}

\section{Kesimpulan}

Infeksi luka operasi (SSI) pada pasien bedah gastrointestinal di Rumah Sakit PKU Muhammadiyah periode Januari hingga Maret 2012 terjadi pada 2 pasien dari total 68 pasien yang keduanya berasal dari rentang usia 41 60 tahun. Namun berdasarkan hasil perhitungan statistik diketahui tidak terdapat hubungan antara umur pasien dengan infeksi luka operasi ( $\mathrm{p}>0,05)$. Selain itu, infeksi luka operasi tersebut juga terjadi pada 2 pasien yang keduanya memiliki penyakit penyerta non diabetes, dan berdasarkan hasil perhitungan statistik diperoleh hasil bahwa terdapat hubungan antara keberadaan penyakit penyerta dengan infeksi luka operasi $(p<0,05)$. Faktor yang berpengaruh terhadap kejadian infeksi luka operasi tidak hanya berasal dari karakteristik pasien yaitu umur dan penyakit penyerta saja, tetapi dapat dipengaruhi oleh banyak faktor yang saling berkaitan untuk menimbulkan kejadian infeksi luka operasi.

\section{Saran}

Perlu dilakukan penelitian mengenai pengaruh imunitas tubuh pasien terhadap kejadian infeksi luka operasi.

\section{DAFTAR PUSTAKA}

Anonim, 2008, SIGN, Scottish Intercollegiate Guidelines Network, AntibioticProphylaxis in Surgery.

http//www.sign.ac.uk., diakses pada tanggal 25 September 2012.

Doherty G.M., 2006, Current Surgical Diagnosis \& Treatment, Twelfth Edition, p.97-107, The McGraw -Hill Companies, United States.

Kanji S., and Devlin J.W., 2008, Antimicrobial Prophylaxis in Surgery In Dipiro J.T. (eds), Talbert, R. (eds), Yee, G. (eds), Matzke, G. (eds), Wells, B. (eds), Posey, M. (eds) Pharmacotherapy A Pathophysiologic Approach Seventh Edition, McGraw-Hill Companies, United States.

Kaye K.S., Schmader K. E., Sawyer R., 2004, Surgical Site Infection in the Elderly Population, Clin Infect Dis 2004; 39:1835-41.

Korner H., Sondenaa K., Soreide J. A., Andersen E., Nysted A., Lende T. H., Kjellevold K. H., 1997, Incidence of Acute Nonperforated and Perforated Appendicitis : Age-specific and Sex-specific Analysis, World J. Surg. 21, 313-317.

Mangram A. J., Horan T. C., Pearson M. L., Silver L. C., Jarvis W. R., 1999, Guideline for Prevention of Surgical Site Infection, Infect Control Hosp Epidemiol 1999; 20 : 247-280.

Prystowsky J. B., Pugh C. M., Nagle A. P., 2005, Current Problems in 
Surgery. Appendicitis., Curr Probl Surg. 2005 Oct;42(10):688-742.

Tietjen L., Bossemeyer D., Mclntosh N., 2003, Infection Prevention Guideline for Healthcare Facilities with Limited Resources Chapter 23, JHPIEGO Corporation, United States. 